\title{
Geospatial Applications in Land Use/Land Cover Change Detection for Sustainable Regional Development: The Case of Central Haryana, India
}

\begin{abstract}
Timely and accurate detection of land use/land cover (LULC) change is important for the macro and micro level sustainable development of any region. For this purpose, geospatial techniques are the best tool for change analysis as they supply timely, cheaper, precise and up to date information. This paper examines the spatial temporal change trend in LULC in the case of Central Haryana. Landsat 2, 3, 5, 7 and 8 images for the years 1975-2020 for pre- and post-monsoon periods were analyzed for the study. Radiometric correction was performed to derive better information. ArcGIS 10.2 and ENVI 5.3 are used for thematic layout and thematic change preparation. An unsupervised classification using ERDAS IMAGINE 2015 has also been done to classify study area in eight classes. The year 1975 is considered as the base year for change detection analysis. Results showed an increasing trend for the land use classes of built-up, water body, and agricultural land without waterlogging in the preand post-monsoon periods between 1975 and 2020. Remaining land use classes of agriculture with waterlogging, open waterlogged area, vegetation and fallow land/sand dunes decreased during the same period. Increased human activities have changed the LULC in the region and have had a great impact on its sustainable regional development.
\end{abstract}

Keywords: geospatial, India, land use/land cover, RS-GIS, sustainable regional development, thematic change

Received: 27 January 2021; accepted: 15 March 2021

(C) 2021 Authors. This is an open access publication, which can be used, distributed and reproduced in any medium according to the Creative Commons CC-BY 4.0 License.

Research Scholar, Lovely Professional University, Punjab, India

Lovely Professional University, School of Humanities, Department of Geography, Punjab, India, email: ripudaman1@hotmail.com,ripudaman.17178@1pu.co.in,

ORCID ID: https://orcid.org/0000-0001-5141-7760 


\section{Introduction}

In the era of mechanization, alterable land use and land cover is very important for environment and development purposes. Land use is defined as the land, which is used for cultural activities while land cover refers to land covered by natural components [1-3]. Land use and land cover are continuously altered by humans, who are the most exterminatory agents on earth. Historically, human beings changed the landscape through industrialization, urban planning, settlements, agriculture development and for wellbeing and their survival [4]. Land use and land cover change as modified structure, position and number of landscapes increasing or decreasing in forms, can be studied through remote sensing data over spatio-temporal aspects [5]. In this regard, geospatial application is the best tool for land use and land cover analysis [6].

Worldwide, considerable research has been undertaken to monitor land use and land cover change. The best understanding of change detection is necessary to understand the interaction between human activities, natural resources and environment $[7,8]$. During the nineteenth century, land use and land cover changes were monitored by traditional methods. However, with the emergence of remote sensing and advancements in geospatial technology, monitoring of land use/land cover change have become more economical, time saving, reliable and up to date [9-11]. Satellite images provide valuable information about land use and land cover, and change can be ascertained from temporal geospatial data [12,13]. Various techniques and methods have been applied for land use and land cover mapping and change detection after 1990 [14, 15]. Extensive previous research has observed the rapid change in land use/land cover globally [16].

Amongst developing countries, numerous studies have been conducted to study land use and land cover in India and its numerous regions [17], including a number of studies on land use and land cover change detection in Haryana. LULC change has been monitored in the northern part of Gurgaon adjoining Delhi and it was found that settlements and closed forest areas have increased while cropped and wasteland areas have declined [18]. Land cover in the Fatehabad district in Haryana was mapped with geospatial techniques [19]. For Faridabad district, the land use and land cover change from 2002-2021 was studied, which showed a decline in the agricultural area but increased urban land use [20].

In the modern period of fast growth, anthropogenic activities, mainly urbanization, growing population levels and industrialization generate imbalances in natural ecosystem. LULC is changing in both positive and negative aspects. Positive change means unusable land is changing into usable land by modern techniques while the negative aspect means that usable land is degrading. LC change analysis is considered as an important factor for micro level development and environmental change [21, 22]. Various studies have been undertaken already to analyze land use 
and land cover change utilizing different methodologies and satellite data [23-25]. Another study analyzed land use and land cover change with remote sensing application for sustainable development, and found that the built-up area has been increasing significantly in the greater Dhaka region of Bangladesh, while water bodies, vegetation cover, wetland and crop land have been continuously decreasing over time. Land use and land cover mapping has been found to be useful for sustainable urban expansion decisions in this respect [26].

Land use and land cover change affected by human interference in Central Haryana has been a prominent concern in the last few decades. Keeping all such facts in mind, the land use and land cover change detection from spatial and temporal perspectives has been undertaken to analyze the LULC in Central Haryana. The main objective of this study is to assess the land use and land cover change in the Central Haryana region from 1975 to 2020 for pre- and post-monsoon periods to analyze its impact on regional sustainable development. The year 1975 is determined as the baseline for assessing the change detection. Landsat 2, 3, 5, 7 and 8 data have been used for the LULC change analysis. The study highlights the thematic change of Central Haryana vis a vis the impact of land use and land cover change on its sustainable development.

\section{Study Area}

The Central Haryana region comprises of 23 blocks of the Rohtak, Jhajjar, Sonipat, Jind, Hisar, Bhiwani and Charkhi Dadri districts. The extent of the study area is $28^{\circ} 21^{\prime}$ to $29^{\circ} 27^{\prime} \mathrm{N}$ and $75^{\circ} 55^{\prime}$ to $77^{\circ} 00^{\prime} \mathrm{E}$. It is bounded by Delhi, the remaining areas of Sonipat, and Gurugram districts in the east; Karnal and Jind districts in the North; the remaining parts of Hisar, Charkhi Dadri and Bhiwani districts in the west and Rewari district in the south (Fig. 1). The total area of the study region is $7715.57 \mathrm{~km}^{2}$. It is covered by the Ghaggar-Yamuna plain, which is formed by alluvial and aeolian depositions of Pleistocene to Holocene age. Mostly the area has an elevation of 201-250 m, while the southern part of the study area has an elevation of 251-300 m. Aeolian plain, older alluvial plain, dune complex and sand dunes are the major geomorphological landforms of the region. It enjoys $30-110 \mathrm{~cm}$ average annual rainfall and $24.6-25.00^{\circ} \mathrm{C}$ mean annual temperature. Sahibi Nadi, Western Yamuna canal and Jui canal are the major sources of irrigation in the Central Haryana. Sierozem and Solemnized types of soil are found here, while sub-tropical dry deciduous forest trees are the vegetation in the study area. Groundwater falls in the categories of safe, critical, semi critical and over exploited [27]. Central Haryana is the agrarian dominated part of Haryana, where the total population of the study area was 3,999,019 in the 2011 census. Figure 1 shows the location of the study area. 

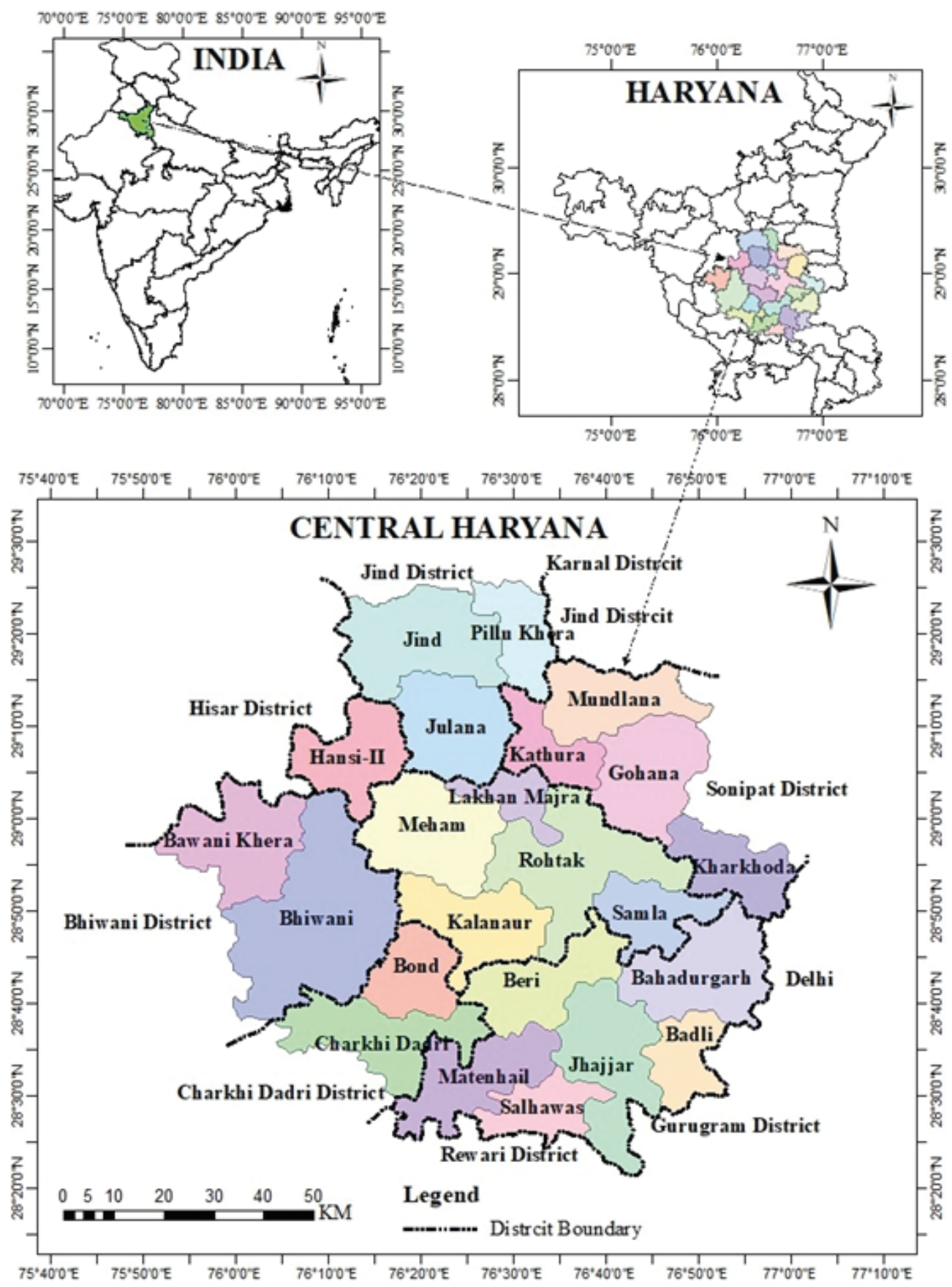

Fig. 1. Location map of study area 


\section{Material and Methods}

The study is based on primary as well as secondary sources of data. Landsat series data (MSS to OLI) for the year of 1975, 1979-1980, 1989-1990, 2000, 2010 and 2019-2020 of pre- and post-monsoon were used for LULC change detection (Tab. 1). All these satellite images were downloaded from the USGS EarthExplorer [28]. Image correction (radiometric correction) is done for Landsat 7 data for the year of 2010 by Landsat Toolbox.tbx [29].

Table 1. Metadata of Landsat series

\begin{tabular}{|c|c|c|c|c||}
\hline $\begin{array}{c}\text { Series } \\
\text { number }\end{array}$ & Satellite and sensor & $\begin{array}{r}\text { Year } \\
\text { (pre- and post-monsoon) }\end{array}$ & $\begin{array}{c}\text { Path/row } \\
\text { and swath [km] }\end{array}$ & Resolution \\
\hline \hline 1 & Landsat 2 (MSS) & 1975 & $158 / 40$ and 185 & 60 \\
\hline 2 & Landsat 3 (MSS) & $1979-1980$ & $158 / 40$ and 185 & 30 \\
\hline 3 & Landsat 5 (TM) & $1989-1990$ & $147 / 40$ and 185 & 30 \\
\hline 5 & Landsat 7 (ETM+) & $2000-2010$ & $147 / 40$ and 185 & 30, 15_Pan \\
\hline 5 & Landsat 8 (OLI) & $2019-2020$ & $147 / 40$ and 185 & 30, 15_Pan \\
\hline
\end{tabular}

Source: https://www.usgs.gov/core-science-systems/nli/landsat/bulk-metadata-service

Pre-field and post-field visits were carried out to identify and verify the various classes of land use and analyzing the LULC change during the study period. The area under reference is categorized into eight classes such as:

1) built-up area;

2) water body;

3) agriculture land without waterlogging;

4) agriculture land with waterlogging;

5) open waterlogged area;

6) salinity affected area;

7) vegetation;

8) fallow land/sand dunes.

ERDAS IMAGINE 2015 was used for unsupervised classification and ArcGIS 10.2 for map creation. Thematic change was done in ENVI 5.3 software. Detailed methodology used for the study is depicted in Figure 2. 


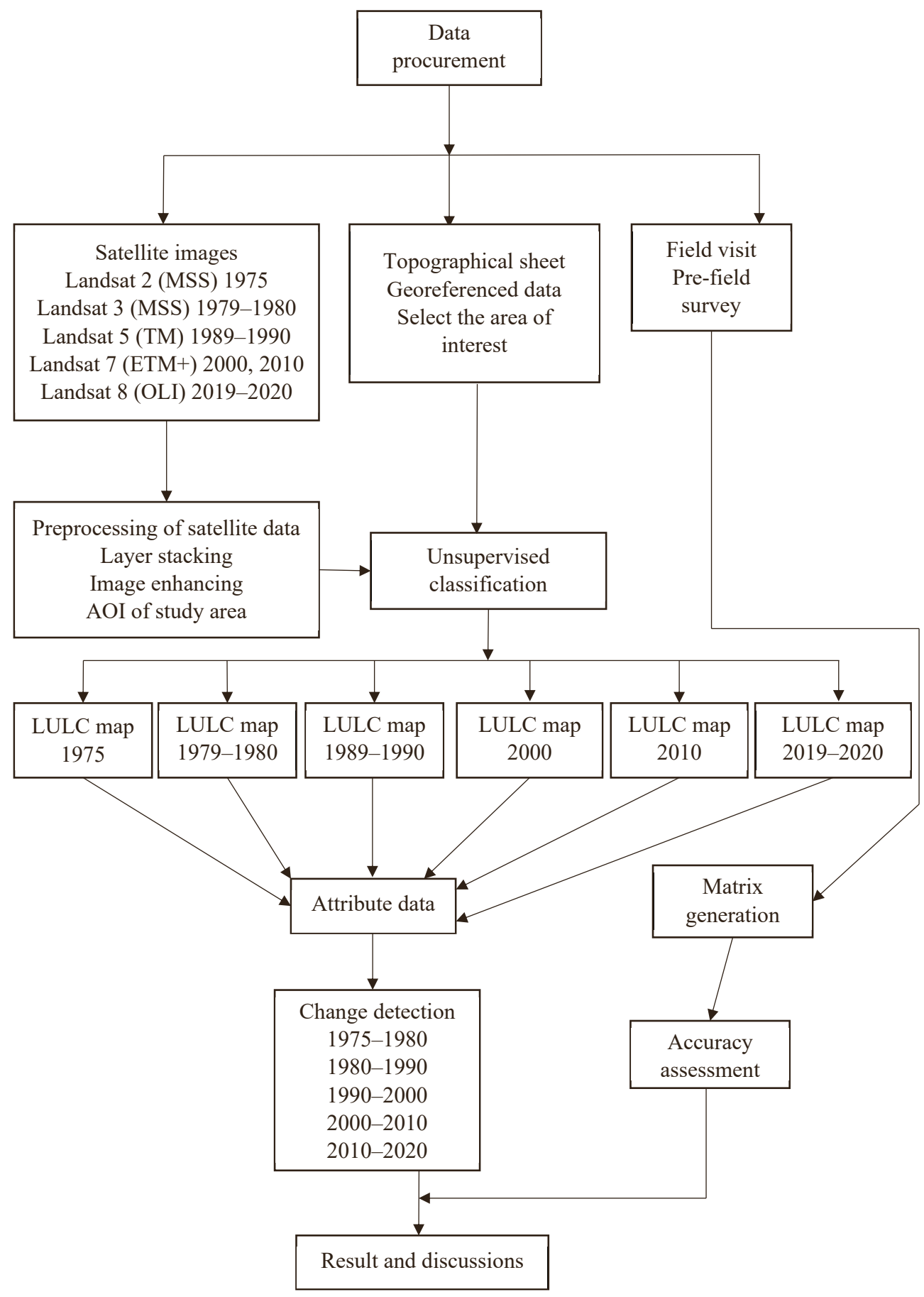

Fig. 2. Flow chart of methodology 


\section{Discussions and Analysis}

\subsection{Land Use and Land Cover Classification}

The Central Haryana region is classified into eight classes from Landsat series data of pre- and post-monsoon periods. Land use and land cover shows changing patterns in the study area. Built-up area, agriculture land and salinity show an increasing trend, whereas a decreasing trend is found in vegetation cover, while others classes are best described as fluctuating trends. Figures 3 and 4 show the LULC classification of the study area, and Table 2 shows the area of each and every class, which presents the LULC spatial-temporal distribution for pre- and post-monsoon period of the Central Haryana. A look at the data indicates that in the pre-monsoon classes 1, 2, 3 showing an increasing trend and 7 showing a decreasing trend, while remaining classes show a fluctuating trend. In the post-monsoon periods, area of classes 1,2 are increasing, for 7 decreasing, while others classes having fluctuating trends. A major change can be observed in vegetation class, where about $85 \%$ area of vegetation is transferred to other classes from 1975 to 2020. Built up areas recorded a 65\% increase for the same period. Meanwhile, agricultural land without waterlogging increased $72 \%$ and $79 \%$ in pre- to pre-monsoon and post- to post-monsoon periods from 1975 to 2020. Fallow land/sand dune areas declined by 70\% from 1975 (pre-monsoon) to 2020 (pre-monsoon), while a major decline was detected from 2000 onwards.

Table 2. LULC classification of pre- and post-monsoon seasons [ha]

\begin{tabular}{|c|c|c|c|c|c|c|c|c|c|}
\hline \multirow{2}{*}{\multicolumn{2}{|c|}{ Year }} & \multicolumn{8}{|c|}{ Class } \\
\hline & & 1 & 2 & 3 & 4 & 5 & 6 & 7 & 8 \\
\hline \multirow{2}{*}{1975} & pre & 94436 & 8071 & 320432 & 56218 & 43515 & 33309 & 55208 & 160311 \\
\hline & post & 94858 & 8080 & 272019 & 85112 & 47930 & 32380 & 53076 & 178045 \\
\hline \multirow{2}{*}{ 1979-1980 } & pre & 95145 & 8460 & 327410 & 39722 & 43041 & 34890 & 52408 & 170424 \\
\hline & post & 95404 & 8510 & 191493 & 47127 & 47837 & 34681 & 47433 & 299015 \\
\hline \multirow{2}{*}{ 1989-1990 } & pre & 100452 & 8789 & 332311 & 47012 & 42039 & 35941 & 43991 & 160965 \\
\hline & post & 100510 & 8805 & 292192 & 50672 & 50331 & 33484 & 40433 & 195073 \\
\hline \multirow{2}{*}{2000} & pre & 112427 & 8882 & 383068 & 85400 & 43665 & 37133 & 35429 & 65496 \\
\hline & post & 113071 & 8912 & 324311 & 94209 & 48890 & 35208 & 33954 & 112945 \\
\hline \multirow{2}{*}{2010} & pre & 124347 & 9078 & 412390 & 83579 & 40825 & 38979 & 21414 & 40888 \\
\hline & post & 125904 & 9120 & 332324 & 113520 & 84975 & 35526 & 19899 & 50232 \\
\hline \multirow{2}{*}{ 2019-2020 } & pre & 144164 & 9470 & 439555 & 54408 & 38029 & 39256 & 8490 & 38128 \\
\hline & post & 145910 & 9510 & 344030 & 28790 & 41277 & 37188 & 7986 & 156809 \\
\hline
\end{tabular}

Explanations: 1 - built-up, 2 - water body, 3 - agriculture land without waterlogging, 4 - agriculture land with waterlogging, 5 - open waterlogged area, 6 - salinity affected area, 7 - vegetation cover, 8 - fallow land/sand dune.

Source: ArcGIS software calculations from derived spatial data from satellite images 

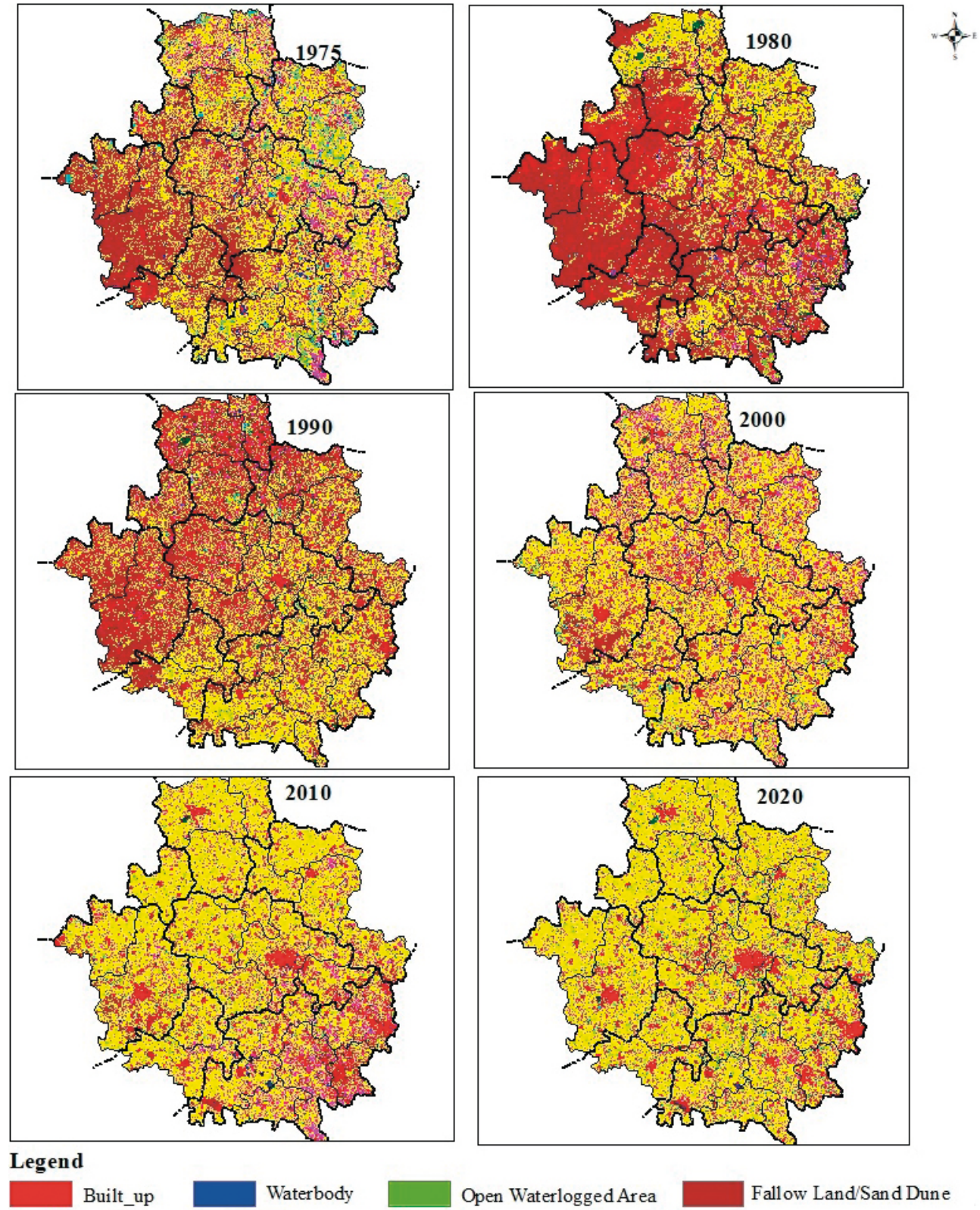

Open Waterlogged Area

Fallow Land/Sand Dune

Vegetation Agriculture With out Waterlogging Salinity Affected Area $\bigcirc$ Block_Boundary -.-..-.. District_Boundary

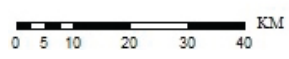

Fig. 3. Unsupervised image classification LULC, pre-monsoon period (1975-2020),

Central Haryana 

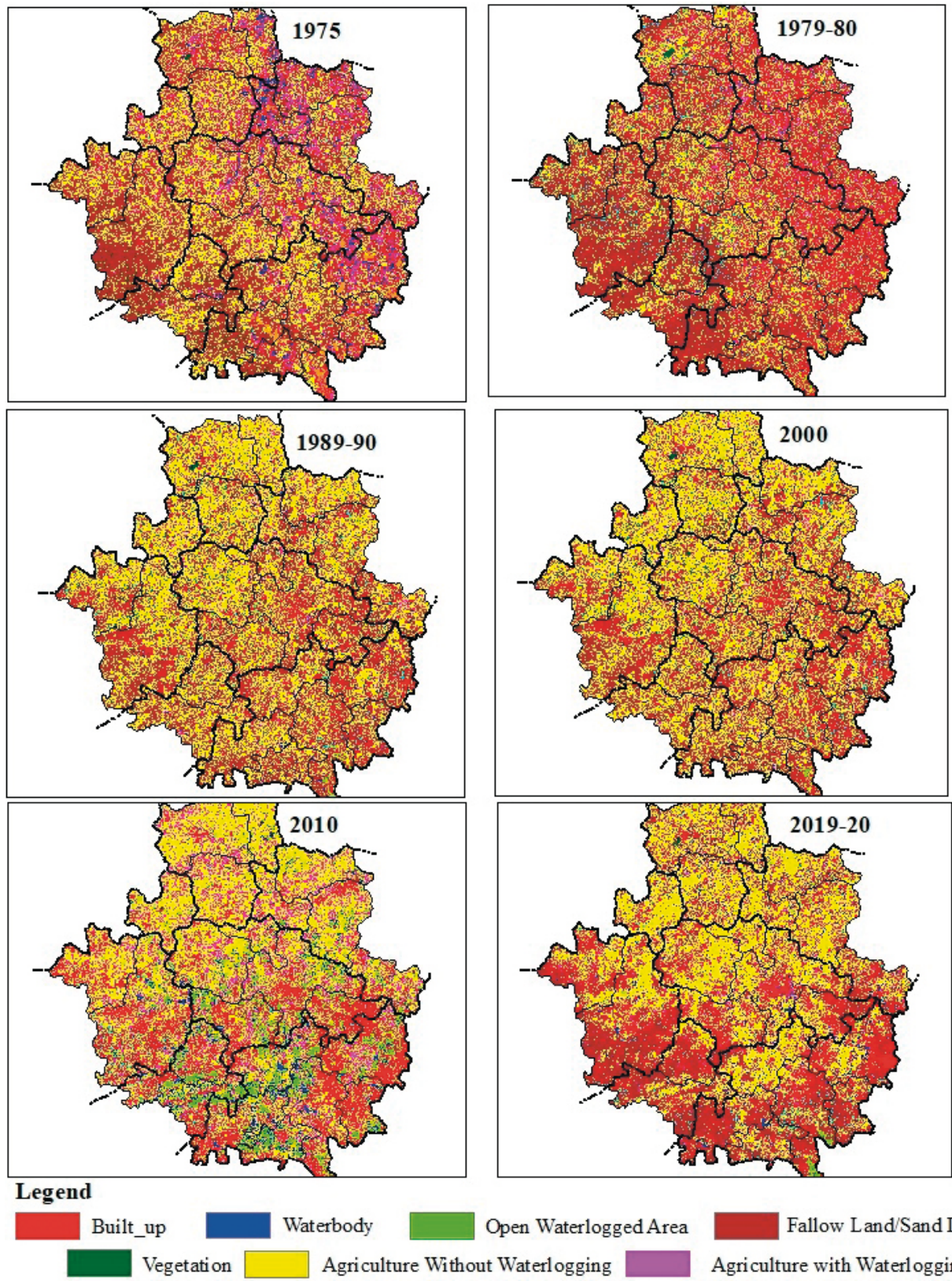

Waterbody

Open Waterlogged Area

Fallow Land/Sand Dune

\begin{tabular}{lllll}
\hline \begin{tabular}{l}
0 \\
\hline
\end{tabular}$\frac{5}{10}$ & 20 & 30 & 40
\end{tabular} Agriculture Without Waterlogging Agriculture with Waterlogging

Salinity Affected Area $\bigcirc$ Block_Boundary --.-.-- District_Boundary

Fig. 4. Unsupervised image classification LULC, post-monsoon period (1975-2020),

Central Haryana 


\subsection{Change Detection and Analysis of Its Impact on Regional Sustainable Development}

\section{LULC Change Detection}

Table 3 depicts the change of pre- to pre-monsoon and post- to post-monsoon periods for the years 1975-1980, 1980-1990, 1990-2000, 2000-2010, 2010-2020 and 1975-2020.

Table 3. Temporal pre- to pre-monsoon and post- to post-monsoon change detection

\begin{tabular}{|c|c|c|c|c|c|c|c|c|c|}
\hline \multirow{2}{*}{\multicolumn{2}{|c|}{ Year }} & \multicolumn{8}{|c|}{ Class } \\
\hline & & \multirow{2}{*}{$\frac{1}{709}$} & \multirow{2}{*}{$\frac{2}{389}$} & \multirow{2}{*}{$\begin{array}{c}3 \\
6978\end{array}$} & \multirow{2}{*}{$\begin{array}{c}4 \\
-16496\end{array}$} & \multirow{2}{*}{$\frac{5}{-414}$} & \multirow{2}{*}{$\frac{6}{1581}$} & \multirow{2}{*}{$\begin{array}{c}7 \\
-2800\end{array}$} & \multirow{2}{*}{$\begin{array}{c}8 \\
10113\end{array}$} \\
\hline & $\mathrm{P}$ to $\mathrm{P}$ & & & & & & & & \\
\hline & $\mathrm{Pt}$ to $\mathrm{Pt}$ & 546 & 430 & -80256 & -37985 & -93 & 2301 & -5743 & 120970 \\
\hline \multirow{2}{*}{ 1980-1990 } & $\mathrm{P}$ to $\mathrm{P}$ & 5307 & 279 & 4901 & 7290 & -1002 & 1051 & -8417 & 9459 \\
\hline & $\mathrm{Pt}$ to $\mathrm{Pt}$ & 5106 & 295 & 100699 & 3545 & 2494 & -1197 & -6900 & -103942 \\
\hline \multirow{2}{*}{ 1990-2000 } & $\mathrm{P}$ to $\mathrm{P}$ & 11975 & 93 & 50757 & 38388 & 1626 & 1192 & -8562 & -95469 \\
\hline & $\mathrm{Pt}$ to $\mathrm{Pt}$ & 12561 & 107 & 32119 & 43537 & -1441 & 1724 & -6479 & -82128 \\
\hline \multirow{2}{*}{ 2000-2010 } & $\mathrm{P}$ to $\mathrm{P}$ & 11920 & 196 & 29322 & 1821 & -2840 & 1846 & -14015 & -24608 \\
\hline & $\mathrm{Pt}$ to $\mathrm{Pt}$ & 12833 & 208 & 8013 & 19311 & 36085 & 318 & -14055 & -62713 \\
\hline \multirow{2}{*}{ 2010-2020 } & $\mathrm{P}$ to $\mathrm{P}$ & 19817 & 392 & 27165 & -29171 & -2796 & 277 & -12924 & -2760 \\
\hline & $\mathrm{Pt}$ to $\mathrm{Pt}$ & 20006 & 390 & 11706 & -84730 & -43698 & 1662 & -11913 & 106577 \\
\hline \multirow{2}{*}{ 1975-2020 } & $\mathrm{P}$ to $\mathrm{P}$ & 49728 & 1399 & 119123 & -1810 & -5486 & 5947 & -46718 & -122183 \\
\hline & $\mathrm{Pt}$ to $\mathrm{Pt}$ & 51052 & 1430 & 72011 & -56322 & -6653 & 4808 & -45090 & -21236 \\
\hline
\end{tabular}

Explanations: 1 - built-up, 2 - water body, 3 - agriculture land without waterlogging, 4 - agriculture land with waterlogging, 5 - open waterlogged area, 6 - salinity affected area, 7 - vegetation cover, 8 - fallow land/ sand dune; $\mathrm{P}$ - pre-monsoon, $\mathrm{Pt}$ - post-monsoon.

Source: derived from Table 2

Figures 5, 6 on the interleaf and 7 show the thematic change of classified area. Tables 3-5 show the thematic area which is transformed into another class during pre- and post-monsoon periods. Based on classified map of 1975, 1979-1980, 1989-1990, 2000, 2010 and 2019-2020 of pre- and post-monsoon periods, land use and land cover changes were detected in Central Haryana. 


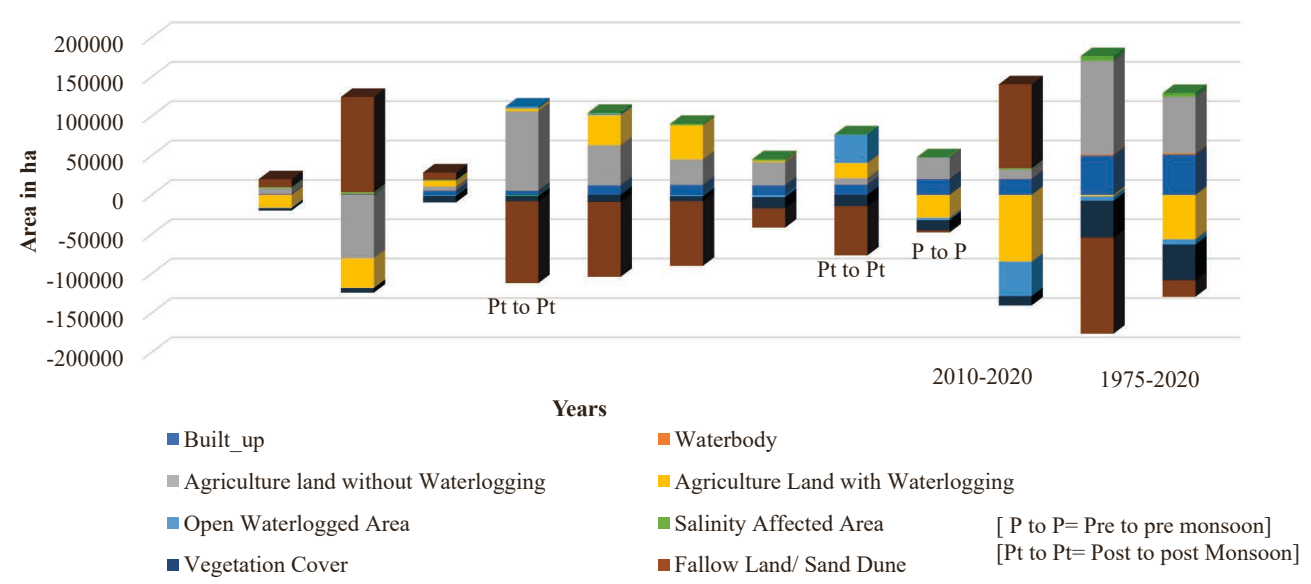

Fig. 7. LULC change detection, pre- to pre-monsoon and post- to post-monsoon periods, Central Haryana

\section{Impacts of LULC on Regional Sustainable Development}

LULC change impacts the cultural and physical factors of any region. These dynamic changes must be analyzed when taking any decision for development. Regular and time to time monitoring of LULC change is helpful in providing detailed analysis of LULC impacts. Landsat series data were used to analyze the impact of land use and land cover change on regional sustainable development in the Central Haryana.

\section{Built-up Area Change}

The population has increased continuously in the study area between 1975 and 2020, as has the amount of built-up areas. Built-up land area was 94,436 and 94,858 ha in 1975 and increased 144,164 and 145,910 ha in 2020 in the pre- and post-monsoon periods. The increasing trend shows that built up areas have increased rapidly, with the concomitant rise in population in the area being the main cause of this. As a result, attention should be focused on this fast-growing class in order to prevent stress on the environment.

\section{Waterbody Area Change}

Water is most essential part of life and plays an important role in various human activities such as agricultural, industrial, fishing, energy sources, transportation, forestry and drinking etc. [19]. An increasing population pressurizes the available water sources. In the study area, the water body increased from 1975 to 2020. Water bodies covered an area of 8071 and 8080 ha in 1975, which increased to 9470 and 9510 ha in 2020 in pre- and post-monsoon periods respectively. The water body area changed from 1399 ha in 1975 to 1430 ha in 2020 in the pre- and post-monsoon periods. While the area under water has been increasing, it is noticeable for regional sustainable development that increasing population has adversely affected the 
quantity and quality of water sources in the region. Over exploitation of water resources creates difficulties for the population of the area.

\section{Change in Agriculture Land without Waterlogging and with Waterlogging}

Central Haryana is the agriculture dominated part of Haryana. Agriculture is the main occupation of the people of the study area. Agricultural area without waterlogging was 320,432 and 272,019 ha in 1975 which increased to 439,555 and 344,030 ha in 2020 in both pre- and post-monsoon periods. The area changed as 119,123 and 72,011 ha from 1975 to 2020 for both monsoon periods. The agriculture area with waterlogging was 56,218 and 85,112 ha in pre- and post-monsoon periods in 1975 which decreased to 54,408 and 28,790 ha in 2020. The agricultural area with waterlogging was changed from -1810 to $-56,322$ ha between 1975 and 2020 in both periods. With the increasing population stress on agricultural land, degradation problems have arisen and, in such situations, regional development declines. So regular LULC change monitoring is essential towards regional sustainable development to control land degradation.

\section{Change in Open Waterlogged Area}

The waterlogging problem has been fluctuating in the study area, where unwanted irrigation practices, canal seepage and depressed basin area are the major causes of this problem. The trend in waterlogged areas fluctuated from 1975 to 2020 in the pre- and post-monsoon periods. Open waterlogged area covered 43,515 and 47,930 ha in the pre- and post-monsoon periods in 1975 while the area decreased to 38,029 and 41,277 ha in 2020 . Waterlogging area changed from -5486 to -6653 ha between 1975 and 2020 in both periods. The waterlogging problem is therefore decreasing year on year [27]. Detailed information about degraded land helps providing accurate decision-making policies for sustainable regional development.

\section{Salinity Affected Area Change}

The salinity affected area has increased continuously. In 1975, 33,309 and 32,380 ha were classified as such areas in the pre- and post-monsoon periods, which increased to 39,256 and 37,188 ha in 2020 in pre- and post-monsoon periods. Poor quality groundwater was used for over irrigation, which makes the soil saline. The increasing trend of salinity requires urgent attention to address the problem. For regional sustainable development, this type of land degradation problem should be minimized and regularly monitored to prevent its spread.

\section{Vegetation Area Change}

Vegetation is a valuable resource for regional sustainable development. The vegetation area was 55,208 and 53,076 ha in 1975 but decreased to 8490 and 7986 ha in 2020 in pre- and post-monsoon periods. Increasing population and industrial development are responsible for decreased vegetation cover in the study area. Strong 
decisions are required for vegetation protection. If the vegetation cover decreases continuously, then an emerging deforestation situation will occur which will directly and indirectly impact the human activities and regional development.

\section{Fallow Land/Sand Dunes Area Change}

Waste land in the study area is transformed into other classes and this transformed area is used for development activities. In 1975, 160,311 and 178,045 ha were in this category, which decreased to 38,128 and 156,809 ha in pre- and post-monsoon periods in 2020. The area under fallow land/sand dunes was changed from $-122,183$ to -21,236 ha between 1975 and 2020 in both monsoon periods. With many developmental activities often related to housing, and the expansion of built-up areas, the amount of land in this class decreased. Detailed information about these types of areas helps in town and country planning, rehabilitation and land conservation in order to achieve sustainable regional development.

Table 3 analyzed the LULC change of pre- to pre-monsoon and post- to post-monsoon periods of the study area. From 1975 to 2020, built-up, water body, agricultural land without waterlogging and salinity affected areas increased as 49,728; 1399; 119,123 and 5947 ha in pre-monsoon and 51,052; 1430; 72,011 and 4808 ha in post-monsoon periods respectively. Remaining classes, such as agriculture with waterlogging, open waterlogged area, vegetation and fallow land/sand dunes have decreased from 1975 to 2020 as $-1810 ;-5486 ;-46,718$ and $-122,183$ ha in pre-monsoon and $-56322 ;-6653 ;-45,090$ and 21,236 ha in post-monsoon periods respectively.

Thematic change is depicted in Tables 4 and 5, which describe class to class transformation in the study area.

Table 4. Class to class change from 1975 to 2020 (pre-monsoon)

\begin{tabular}{|c|c|c|c|c|c|c|c|c||}
\hline Class & BP & WB & ALWOW & ALWW & OW & SL & Veg. & FL/SD \\
\hline \hline BP & 49728 & 0.00 & 0.00 & 0.00 & 0.00 & 0.00 & 0.02 & 0.00 \\
\hline WB & 2.00 & 1399 & 0.88 & 0.00 & 0.00 & 0.00 & 0.13 & 3.00 \\
\hline ALWOW & 21397 & 179.7 & 119123 & 1103 & 1508 & 2785 & 99.2 & 49902 \\
\hline ALWW & 1955 & 302.2 & 57028 & -1810 & 3442 & 1231 & 114.2 & 39476 \\
\hline OW & 3096 & 294 & 7968 & 100.4 & -5486 & 1012 & 80 & 9609 \\
\hline SL & 9179 & 23 & 715.82 & 91.5 & 49.79 & 5947 & 112.9 & 21721 \\
\hline Veg. & 7283 & 14.1 & 357.1 & 206.6 & 9.71 & 18 & -46718 & 1472 \\
\hline FL/SD & 6816 & 586 & 53053.2 & 308.5 & 476.5 & 901 & 65.8 & -22183 \\
\hline \hline
\end{tabular}

Explanations: BP - built-up, WB - water body, ALWOW - agriculture land without waterlogging, ALWW - agriculture land with waterlogging, OW - open waterlogged area, SL - salinity affected area, Veg. - vegetation cover, FL/SD - fallow land/sand dune. 
Table 5. Class to class change from 1975 to 2020 (post-monsoon)

\begin{tabular}{||c|c|c|c|c|c|c|c|c||}
\hline Class & BP & WB & ALWOW & ALWW & OW & SL & Veg. & FL/SD \\
\hline \hline BP & 51052 & 0.00 & 0.00 & 0.00 & 0.00 & 0.00 & 0.00 & 0.00 \\
\hline WB & 0.2 & 1430 & 0.00 & 0.00 & 0.00 & 0.00 & 0.13 & 0.06 \\
\hline ALWOW & 8719 & 179.27 & 72011 & 18304 & 3204.4 & 2285 & 99.2 & 12847 \\
\hline ALWW & 1955 & 265.2 & 9028 & -56322 & 944.2 & 933 & 114.2 & 3476 \\
\hline OW & 2496 & 729.48 & 8193.6 & 24938 & -6653 & 143 & 80 & 1860 \\
\hline SL & 8118 & 23.25 & 715.8 & 191.5 & 49.7 & 4808 & 112.9 & 2946 \\
\hline Veg. & 1283.8 & 14.2 & 9357.1 & 2009.5 & 9.6 & 18.0 & -45090 & 107 \\
\hline FL/SD & 28480 & 218.6 & 44716.5 & 10879 & 2445.1 & 1429 & 65.8 & -21236 \\
\hline
\end{tabular}

Explanations: BP - built-up, WB - waterbody, ALWOW - agricultural land without waterlogging, ALWW - agriculture land with waterlogging, OW - open waterlogged area, SL - salinity affected area, Veg. - vegetation cover, FL/SD - fallow land/sand dune.

Source: derived from Table 2

It designates pre- to pre-monsoon and post- to post-monsoon spatial temporal change in particular class. These data explain how much area of a class has been increased or decreased during the time periods. Apart from this, other data in the tables show one class to another class transformation from 1975 to 2020 (pre-monsoon and post-monsoon) periods. Analysis shows that vegetation area, fallow land/ sand dunes, open waterlogged area and agriculture with waterlogging area are continuously transforming into the built-up, water body, agriculture without waterlogging and salinity classes. Major changes are seen in vegetation and fallow land/sand dunes class to agriculture and built-up classes. It is pertinent that fallow land/sand dunes, open waterlogged area and agriculture land with waterlogging decreased in pre-monsoon periods than post-monsoon periods.

\section{Agricultural and Population Growth Analysis}

Central Haryana is an agriculture dominated region of Haryana state. The agricultural area and population of the study area have been analyzed and are depicted in Figure 8.

The agricultural area has decreased by $-9.5 \%$ from 1975 to 1980, but after that fluctuating trend is reflected as $13.68,10.73,4.83$ and 5.03 percent increase in 1980-1990, 1990-2000, 2000-2010 and 2010-2020 respectively. The decadal growth of the population of Central Haryana was 28.75, 27.41, 28.43, 29.9 and 30.2\% in 1980, 1990, 2000, 2010 and 2020 respectively. It shows that the decadal growth of the population has been much higher than the decadal growth of agriculture. If the current growth rates remain the same in the future as well, food crises will be imminent. 
Increasing built up areas, combined with decreased agriculture land and growing food demands by an expanding population will certainly cause problems in food security and sustainable regional development in the future. It has also been shown that the significant loss of agricultural land among various developing countries (like those in South Asia and Sub-Saharan Africa), destabilizes biodiversity, unbalances ecosystems and increases food insecurity [31, 32].

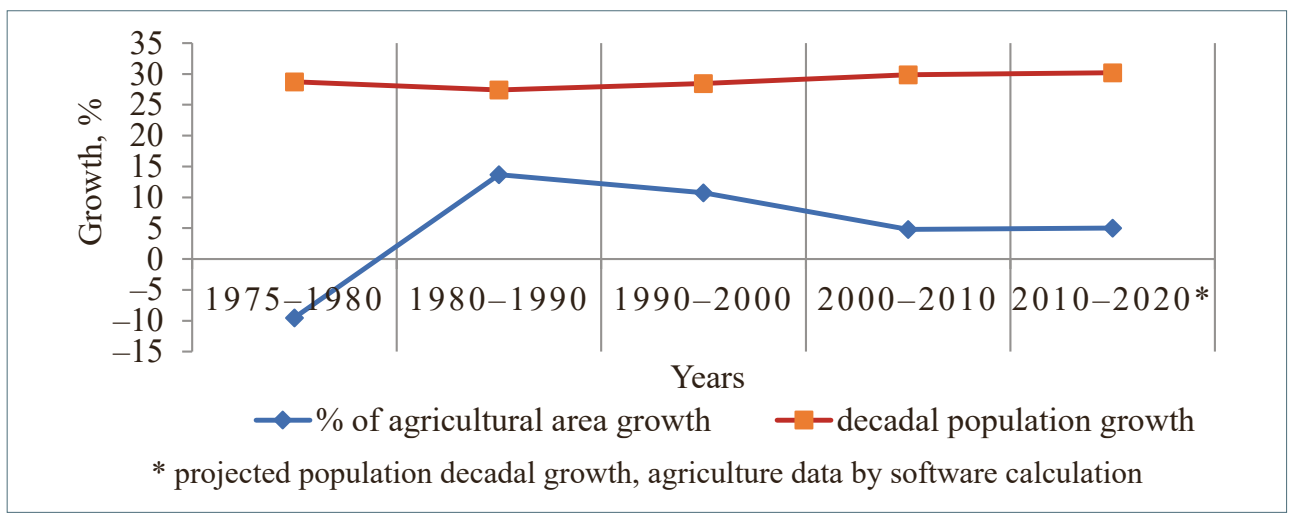

Fig. 8. Agriculture area and population, decadal growth analysis (1975-2020), Central Haryana

Source: [30]

\section{Conclusions}

LULC change impacts the environment, ecosystem and sustainable development of a region. Therefore, it is necessary to get detailed and reasonable information about LULC to achieve regional sustainable development at all levels. Geospatial technique-based results become more reliable and precise after ground truth verification. LULC transformation in Central Haryana is mainly caused by human induced activities. The transformation of LULC has been effectively captured by geospatial data. The study area has witnessed extensive changes in the pattern of LULC over the last five decades. Out of eight classes, built-up, water body, agriculture land without waterlogging and salinity have registered increasing trends, while agriculture with waterlogging, open water-logged area and fallow land/sand dunes have witnessed fluctuating trends. Vegetation cover has been showing a continuous decline. Such studies depicting LULC transformation may be useful in decision and policy making and may help policy makers and administrations towards achieving sustainable development goals. Furthermore, it will also be helpful in assessing the cause and consequences of land use and land cover transformation in an agriculturally developed region like Central Haryana. 


\section{References}

[1] Burley T.M.: Land use or land utilization? Professional Geographer, vol. 13, no. 6, 1961, pp. 18-20. https://doi.org/10.1111/j.0033-0124.1961.136_18.x.

[2] Lo C.P.: Applied Remote Sensing, Geocarto International, vol. 60, issue 4, 1986, p. 60. https://doi.org/10.1080/10106048609354071.

[3] Chamling M., Bera B.: Spatio-temporal patterns of land use/ land cover change in the Bhutan-Bengal foothill region between 1987 and 2019: study towards geospatial applications and policy making. Earth Systems and Environment, vol. 4, 2020, pp. 117-130. https://doi.org/10.1007/s41748-020-00150-0.

[4] Taloor A.K., Singh K.V.: Land use land cover dynamics using remote sensing and GIS techniques in Western Doon Valley, Uttarakhand, India. [in:] Sahdev S., Singh R.B., Kumar M. (eds.), Geology of Landscape Dynamics, Advances in Geographical and Environmental Science, Springer, 2020, pp. 37-51. https://doi.org/10.1007/978-981-15-2097-6_4.

[5] Stow D.A., Collins D., McKinsey D.: Land use change detection based on multi date imagery from different satellite sensor system. Geocarto International, vol. 5, no. 3, 1990, pp. 3-12. https://doi.org/10.1080/10106049009354263.

[6] Ehelrs M., Jadkowaski M.A., Howard R.R., Brostuen D.E.: Application of SPOT data for regional growth analysis and local planning. Photogrammetric Engineering and Remote Sensing, vol. 58, 1990, pp. 175-180.

[7] Agarwal C., Green G.M., Grove J.M., Evans T.P., Schweik C.M.: A review and assessment of land use change model: dynamics of space, time and human choice. General Technical Report (GTR), U.S. Department of Agriculture, Forest Service, Northeastern Research Station, 2002. https://doi.org/10.2737/ NE-GTR-297.

[8] Jasrotia A.S., Bhagat B.D., Kumar A., Kumar R.: Remote Sensing and GIS approach for delineation of groundwater potential and groundwater quality zones of Western Doon Valley, Uttrakhand, India. Journal of the Indian Society of Remote Sensing, vol. 41, no. 2, 2013, pp. 365-377. https://doi.org/10.1007/ s12524-012-0220-9.

[9] Xiong J., Thenkabail P.S., Gumma M.K., Teluguntla P., Poehnelt J., Congalton R.G., Yadav K., Thau D.: Automated cropland mapping of continental Africa using Google Earth Engine cloud computing. ISPRS Journal of Photogrammetry and Remote Sensing, vol. 126, 2017, pp. 225-244. https://doi.org/10.1016/ j.isprsjprs.2017.01.019.

[10] Noor A.M., Alegana V.A., Gething P.W., Tatem A.J., Snow R.W.: Using remotely sensed night time light as a proxy for poverty in Africa. Population Health Metrics, vol. 6, no. 1, 2008, art. no. 5. https://doi.org/10.1186/1478-7954-6-5. 
[11] William E.R., William B.M., Turner B.L.: Modeling land use and land cover as part of global environment change. Climate Change, vol. 28, no. 1, 2002, pp. 45-64. https://doi.org/10.1007/BF01094100.

[12] Saadat H., Adamowski J., Bonnell R., Sharif F., Namdar M., Ale-Ebrahim S.: Land use and land cover classification over a large area in the Iran based on single data analysis of satellite imagery. ISPRS Journal of Photogrammetry and Remote Sensing, vol. 66, no. 5, 2011, pp. 608-619. https://doi.org/10.1016/ j.isprsjprs.2011.04.001.

[13] Lambin F.E., Geist J.H., Lepers E.: Dynamics of land use and land cover change in Tropical Regions. Annual Review of Environment and Resources, vol. 28, 2003, pp. 205-241. https://doi.org/10.1146/annurev.energy.28.050302.105459.

[14] Jia K., Wei X., Gu X., Yo Y., Xie X., Li B.: Land cover classification using Landsat 8 Operational Land Imager data in Beijing, China. Geocarto International, vol. 29, no. 8, 2014, pp. 941-951. https://doi.org/10.1080/10106049.2014.894586.

[15] Lv Z., Liu T., Wan Y., Benediktsson J.A., Zhang X.: Post-processing approach for refining raw land cover change detection of very high-resolution remote sensing images. Remote Sensing, vol. 10, no. 3, 2018, pp. 2-19. https://doi.org/10.3390/ rs10030472.

[16] Geist H.J., Lambin E.F.: What drivers tropical deforestation? A meta-analysis of proximate and underlying cause of deforestation based on sub national case study evidence. LULC Report Series, no. 4, AGRIS, 2001.

[17] Prakash A., Gupta R.P.: Land use mapping and change detection in a coal mining area - a case study in the Jharia coalfield, India. International Journal of Remote Sensing, vol. 19, issue 3, 1998, pp. 391-410. https://doi. org/10.1080/014311698216053.

[18] Chaudhary B.S., Saroha G.P., Yadav M.: Human Induced Land Use/Land Cover Changes in Northern Part of Gurgaon District, Haryana, India: Natural Resources Census Concept. Journal of Human Ecology, vol. 23, no. 3, 2008, pp. 243-252. https://doi.org/10.1080/09709274.2008.11906077.

[19] Kumar S.: Remote Sensing and Gis Based Groundwater Prospects and Quality Assessment in Fatehabad District, Haryana. i-Manager's Journal on Future Engineering and Technology, vol. 14, no. 1, 2018, pp. 48-54. https://doi. org/10.26634/jfet.14.1.15255.

[20] Nathalia D., Kumar K.E.M., Kishore N., Krishnan G.: Environmental change detection using geo-spatial techniques in Aravalli hills and environs (Faridabad District, Haryana). International Journal of Applied Environmental Sciences, vol. 12, no. 5, 2017, pp. 865-875.

[21] Xiuwan C.: Using remote sensing and GIS to analyze land cover change and its impacts on regional sustainable development. International Journal of Remote Sensing, vol.23, no.1,2002, pp.107-124.http://doi.org/10.1080/01431160010007051. 
[22] Mahiny A.S., Clarke K.C.: Guiding SLEUTH land use/land cover change modeling using multi criteria evaluation: towards dynamics sustainable land use planning. Environment and Planning B: Planning and Design, vol. 39, no. 5, 2012, pp. 925-944. https://doi.org/10.1068/b37092.

[23] Singh A.: Digital change detection techniques using remotely sensed data. International Journal of Remote Sensing, vol. 10, pp. 989-1003. https://doi. org/10.1080/01431168908903939.

[24] Lambin E.F.: Change detection at multiple scales: Seasonal and annual variations in landscape variables. Photogrammetric Engineering and Remote Sensing, vol. 62, no. 8, 1996, pp. 931-938. http://www.asprs.org/wp-content/uploads/ pers/1996journal/aug/1996_aug_931-938.pdf [access: 15.12.2020].

[25] Xiuwan C.:Using remotesensingand GIS to analyzeland coverchangeandits impacts on regional sustainable development. International Journal of Remote Sensing, vol. 23, no. 1, 2002, pp. 107-124. https://doi.org/10.1080/01431160010007051.

[26] Dewan A.M., Yamaguchi Y.: Land use and land cover change in Greater Dhaka, Bangladesh: using remote sensing to promote sustainable urbanization. Applied Geography, vol. 29, no. 3, 2009, pp. 390-401. https://doi.org/10.1016/ j.apgeog.2008.12.005.

[27] Central Groundwater Board: Ground Water Year Book. Ministry of Water Resources, River Development and Ganga Rejuvenation, Government of India, 2014-15.

[28] Landsat Missions: Bulk Metadata Service, Landsat Collection 2. https://www. usgs.gov/core-science-systems/nli/landsat/bulk-metadata-service [access: 15.04.2020].

[29] Tech-Tutor with Fitsum: how to do radiometric correction, Fix Landsat 7 Scan Line Error using Landsat Toolbox in ArcMap. https://www.youtube.com/ user/fitsalem [access: 20.04.2020].

[30] Government of Haryana: Statistical Abstract of Haryana, 2019. Department of Economic and Statistical Analysis, Government of Haryana, Panchkula 2020.

[31] Singh R. (ed.): Re-envisioning Remote Sensing Applications: Perspectives from Developing Countries. CRC Press, Boca Raton 2021. https://doi. org/10.1201/9781003049210.

[32] Maan G.S., Aakanksha, Wasay S., Singh R.: A Comparison of Pixel Based and Object Based Image Analysis with Machine Learning Algorithms for Land Use/Land Cover Classification. Our Heritage, vol. 67, no. 4, 2019, pp. 286-294. 